\title{
SOCIAL MEDIA A KAMPANIE SPOŁECZNE. "FACEBOOK TO NIE ŻYCIE” JAKO PRZYKŁAD KAMPANII SPOŁECZNEJ O I NA FACEBOOKU
}

\author{
Abstract \\ SOCIAL MEDIA AND SOCIAL CAMPAIGNS. „FACEBOOK IS NOT LIFE” \\ AS AN EXAMPLE OF A SOCIAL CAMPAIGN ABOUT AND ON FACEBOOK
}

Today's world, speeding in optical fibers of new technologies, largely focusing on Internet users a variety of social media, forced the non-profit institutions - organizations, foundations education in the fields of social problems using their tools. You do not have Facebook? Today you do not exist say these modern young generation $\mathrm{X}, \mathrm{Y}$ and $\mathrm{Z}$ on high-speed connections drifting across borders globalized world. In it they create its image - professional, personal, intimate. Because a wide range of Facebook, unmatched in the flow of relevant and irrelevant information, and the low cost of the promotion are the arguments, which does not have any traditional medium. Thus leading social campaigns on Facebook opens up significant opportunities. They also apply to two issues directly related to it - undesirable social contacts, rejection or addiction. The first refers to Polski Czerwony Krzyż campaign in 2010 entitled: "Facebook is not life". Through its analysis sought to show how Facebook, based on the mechanisms of rapid and shallow Internet communications, affects interpersonal relationships, especially socializing and what it could have consequences in real life. This step in the social environment rated as fast action, regardless, unconditional and reckless consequences that direct contacts, especially sexual, would be tragic and irreversible.

The campaign was a success. In two days led to social, international discourse (in 150 countries) on the mindless making friends, which usually takes place on Facebook, in the context of prevention of HIV.

Key words: social campaigns, social media, Facebook, social education 


\section{Wstęp}

Kiedy skończyła się era Internetu informacyjnego, a wraz z nim biernego korzystania z sieci, gdzie „(...) jedynym elementem wzajemnego oddziaływania była interakcja, którą można określić jako techniczną”, a „(...) internauta mógł zdecydować tylko o tym, w co kliknie i na jak długo pozostanie na jakiejś stronie" i był „skoncentrowany na wyszukiwaniu i konsumowaniu treści” [Kaznowski 2008, s. 48 i 171], rozpoczął się etap społeczności. Tak zwane social media, które zrewolucjonizowały świat zwykłych ludzi, stanowią dziśs, zaraz po aplikacjach mobilnych, jeden z najszybciej rozwijających się segmentów w branży internetowej. Odbiorca spotyka się z nimi codziennie, chociażby oglądając filmy na YouTubie, sprawdzając informacje na Twitterze czy kontaktując się ze znajomymi na Facebooku. Odpowiadając zatem na społeczną potrzebę dzielenia się informacjami, zyskały one znaczące grono odbiorców, których liczba wciąż rośnie. Dowodem wydaje się popularność największego społecznościowego serwisu - Facebooka, który dotąd zgromadził wokół siebie ponad 1,39 miliarda użytkowników z całego świata (przy czym czynną aktywność wykazuje 890 milionów) [Tur 2015].

Media społecznościowe jednak, mimo wielkiej popularności, są nadal zjawiskiem niedostatecznie zbadanym. Choć do niedawna uchodziły za narzędzie dotyczące rozrywki, bo każda $\mathrm{z}$ użytkujących je osób dzieliła się z innymi użytkownikami tym, co zobaczyła czy przeczytała, to dziś stały się ważnym narzędziem marketingowym także dla marketingu społecznego. Trend wobec „giganta na bardzo solidnych nogach" [Tur 2015], jakim określa się Facebooka, już nienowy, ale ciągle rozwijający się, wzbudził również zainteresowanie nadawców kampanii społecznych, którzy, chcąc dotrzeć do jak największej liczby odbiorców, zostali zmuszeni do wykorzystania tego właśnie narzędzia. Za jego pośrednictwem, a przede wszystkim dzięki możliwości budowania bliskich relacji z użytkownikami w celu interakcji związanej z pożądanym odbiorem społecznego komunikatu i wywołaniem zmiany, aktywność podejmują zarówno podmioty prywatne - fundacje czy organizacje społeczne, ale też państwowe - na przykład ministerstwa kolejnych rządów. W zakresie społecznej edukacji kampaniami, mając możliwość budowania większej świadomości na temat problemów w społeczeństwie, sytuowania się w roli eksperta, a także monitorowania zdania opinii publicznej, starają się oni stworzyć odbiorców społecznie zaangażowanych, nieobojętnych na problemy otaczającego, realnego świata.

Celem niniejszego artykułu jest zobrazowanie Facebooka jako narzędzia wykorzystywanego do edukacji społecznej za pomocą społecznych kampanii na przykładzie „Facebook to nie życie”, czyli kampanii nie tylko umieszczonej na Facebooku, ale i o nim mówiącej, a dokładniej - o jego wybranym aspekcie uznanym współcześnie za społeczny problem. 


\section{Media społecznościowe - interaktywna platforma komunikacji i spotkań}

Dynamiczny rozwój technologii i możliwości technicznych, a zwłaszcza znaczący wzrost liczby osób regularnie korzystających z sieci spowodował gwałtowne zmiany na rynku internetowym. Od wielu lat głównym motorem jego rozwoju były portale, blogi, gry oraz multimedia [Olszański 2012, s. 17]. Za graniczną datę epoki przyjętej za nową, a określonej jako Web 2.0, uznaje się rok 2001. Zweryfikowano wówczas nie tylko strukturę, ale także sposób użytkowania mediów. W rezultacie powstało nowe, aktywne podejście odbiorcy do korzystania z sieci, a ściślej - z nowych kanałów komunikacji; miał on odtąd pełnić funkcję czynną, równie ważną, co projektanci witryn lub ich administratorzy czy właściciele, dodając treści albo modyfikując już istniejące informacje, a nawet tworząc całe elementy otwartych serwisów internetowych [Kaznowski 2008, s. 29].

Trzonem sieci Web 2.0, zdaniem Włodzimierza Gogołka, stały się grupy społecznościowe. Zjawisko powstania tych wirtualnych społeczności określa się jako Internet social networking. Internauci komunikują się tu ze sobą za pośrednictwem wszystkich dostępnych form wymiany informacji. Zauważono przy tym, że wraz ze wzrostem liczby użytkowników zaangażowanych w wirtualne zbiorowości i zainteresowanych komunikowaniem się $\mathrm{w}$ Internecie maleje liczba korzystających $\mathrm{z}$ innych form spędzania czasu w sieci [Gogołek 2010, s. 160].

Filozofia Web 2.0 zmieniła sposób postrzegania Internetu, który przestał być wyłącznie źródłem informacji, a stał się miejscem kontaktów i spotkań. Zaowocowało to powstaniem mediów społecznościowych (ang. social media) [Barefoot 2011, s. 20]. Co ciekawe, japoński socjolog Yoneji Masuda w 1980 roku w książce pt. The Information Society as Post-Industrial Society stwierdził, że: „Nie ma naturalnych granic utrudniających przepływ informacji. Kiedy ukształtuje się globalna przestrzeń informacyjna, ogólnoświatowa komunikacja między ludźmi będzie odbywać się ponad wszelkimi granicami państwowymi” [Brigs, Burke 2010, s. 313314]. Można pokusić się więc o stwierdzenie, że już w 1980 roku Masuda przewidział powstanie social mediów.

Określenie to odnosi się zwykle do korzystania z internetowych technologii w ogólnym pojęciu. Ma służyć przekształceniu komunikacji w interaktywny dialog odbywający się za pomocą mobilnych technologii [Sadowski 2013, s. 80]. Treści pojawiające się w ten sposób stały się jednym z głównych źródeł informacji. A nawet więcej: są łatwe do dzielenia się nimi i, w przeciwieństwie do na przykład przekazu telewizyjnego, interaktywne [tomek 2013]. Charakterystyczne łączenie obrazu, tekstu i dźwięku pozwala uczestnikom wzajemnego oddziaływania wskazać, za pośrednictwem którego z nich będzie przebiegał ich dialog. Mogą oni także wybrać odpowiednie dla siebie medium, zapewniające im komfort $\mathrm{w}$ wybranym sposobie komunikacji. 
Niestety, nie powstała jeszcze jednoznaczna definicja mediów społecznościowych. Choć próbę zdefiniowania tego pojęcia podjęli Andreas M. Kaplan i Michael Haenlein, określając media społecznościowe jako: „(...) grupę internetowych aplikacji opartych na ideologicznych i technologicznych założeniach sieci Web 2.0, które umożliwiają tworzenie i wymianę generowanych przez użytkowników treści” [Kaplan, Haenlein 2010, s. 61], zaś Jay Conrad Levinson i Shane Gibson jako: "(...) zestaw niemal darmowych narzędzi oraz stron internetowych, które pozwalają określonej społeczności na tworzenie treści i prowadzenie znaczącego dialogu w sieci” [Levinson, Gibson 2011, s. 17], to social media nadal pozostają niedookreślone.

Ciekawie prezentuje się definicja mediów społecznościowych zawarta w stwierdzeniu Włodzimierza Gogołka: „Nieformalny monopol mediów na gromadzenie i dystrybucję informacji przestaje istnieć. Inicjatywa w tym zakresie przechodzi do tysięcy indywidualnych osób, których podstawowym kapitałem jest zazwyczaj wyłącznie wiedza o tym, jak samodzielnie uczynić, by określone informacje stały się informacjami publicznymi. Są oni twórcami tak zwanych mediów społecznościowych (social media), przez które rozumie się formę naturalnej, nieskrępowanej wymiany informacji w sieci pomiędzy osobami na temat wspólnych zainteresowań" [Gogołek 2010, s. 160-161].

Patrząc na powyższe ujęcia, za media społecznościowe należy uznać serwisy dające możliwość różnorodnej aktywności użytkownikom sieci, jak wymiana poglądów, rozwijanie zainteresowań, ekspresji oraz interakcji. Działanie social media opiera się więc na powstałych grupach społecznościowych. Motywy przynależności do tych wirtualnych zbiorowości internautów wydają się jednak różne. Większość z nich dotyczy indywidualnych potrzeb użytkowników, zaś elementami je spajającymi są zainteresowania oraz zrozumienie. Zatem powstanie części kanałów mediów społecznościowych (blogów czy mikroblogów, wideo, stron z wiadomościami, podcastów, forów internetowych, a zwłaszcza serwisów społecznościowych) miało na celu ułatwienie komunikacji oraz współpracy między użytkownikami z całego świata [Barefoot 2011, s. 25].

Głównym założeniem, a z czasem ogromnym sukcesem serwisów społecznościowych, takich jak MySpace czy Facebook, stało się budowanie interaktywnych platform komunikacji i spotkań (zawierania znajomości w sieci), czyli funkcjonujących w Internecie relacji międzyludzkich. Dodatkowo portale społecznościowe w większości można założyć, prowadzić i użytkować za darmo. Cechą charakterystyczną jest także ich powszechna osiągalność, warunkowana dostępem do Internetu [Śliwińska 2011, s. 49-51]. Taki stan rzeczy ułatwia korzystanie z nich. Dlatego internauci aktywnie uczestniczą w dziele ich współtworzenia (tak w nich, jak i ich kanałów, do których zalicza się między innymi: Facebook, Twitter, Instagram, MySpace, Pinterest, LinkedIn, Snapchat czy Google+) [Gogołek 2010, s. 161].

Według Dominika Kaznowskiego [Kaznowski 2008] wyróżnia się cztery kategorie sieci społecznych: horyzontalne, profesjonalne, wertykalne i lokalne. Sieci 
horyzontalne nazywane są serwisami społecznościowymi. Koncentrują się na komunikacji między użytkownikami, udostępniając im opcję tworzenia własnych profili, czego przykładem jest bijący rekordy popularności serwis Facebook. Sieci wertykalne natomiast skupiają osoby o podobnych zainteresowaniach, na przykład młodych rodziców lub właścicieli psów. Profesjonalne serwisy mają za zadanie ułatwić komunikację prowadzoną przykładowo w celach biznesowych, zaś lokalne strony pozwalają ich użytkownikom zapoznać się ze sobą i z ważnymi dla nich informacjami.

Każdy serwis wykorzystuje wybrane przez siebie elementy, dzięki którym możliwe staje się nawiązanie kontaktów przez zalogowanych użytkowników, interakcja oraz tworzenie treści. Najczęstszą opcją sieci społecznych jest tworzenie profilu użytkownika, pełniącego funkcję prywatnej strony internetowej. Zakładając go, odbiorca publikuje w nim zdjęcie oraz uzupełnia swoje dane, opisując zainteresowania czy wykształcenie, a tym samym dostarczając innym informacji na swój temat. Równie często portale społecznościowe posługują się listami kontaktów, czyli katalogami profili ludzi, z którymi właściciel profilu pozostaje w relacji. Do wymiany poglądów między większą liczbą osób stosuje się forum dyskusyjne, zapewniające zachowanie historii wypowiedzi. Równie istotnym elementem w funkcjonowaniu każdego serwisu społecznościowego są powiadomienia, mające zwykle formę krótkich komunikatów wysyłanych za pośrednictwem poczty elektronicznej lub wyświetlających się w serwisie w celu poinformowania odbiorcy o zmianach i zdarzeniach na profilu, forach dyskusyjnych czy w listach znajomych. Stanowią one główny czynnik zwiększający liczbę wizyt w serwisie. Komunikatory natomiast umożliwiają porozumiewanie się użytkowników w czasie rzeczywistym. Mogą być one wbudowane w witrynę internetową, jak na przykład Facebook chat, lub pozostać aplikacją zewnętrzną, jak Gadu-Gadu i Skype. Dla zwiększenia atrakcyjności stosuje się także pocztę wewnętrzną, galerie zdjęć, tagi, widgety, ankiety oraz materiały wideo [Kaznowski 2008, s. 102-103].

Media społecznościowe, $\mathrm{w}$ tym serwisy, cieszą się dużą popularnością z kilku powodów. Przede wszystkim niesłychanie szybko odpowiadają na potrzebę przynależności do określonej grupy społecznej. Ułatwiają użytkownikom udostępnianie zdjęć, dokumentów, filmów wideo i utworów muzycznych [Bendyk 2009]. Internauci z całego świata wymieniają się własnymi zasobami, polecają sobie linki; umożliwiają obserwowanie relacji z wydarzeń z życia pozostałych użytkowników oraz wyrażanie własnej indywidualności. Zamieszczając informacje o sobie i chwaląc się sukcesami, budują poczucie własnej wartości oraz status społeczny [Sokołowski 2008, s. 346].

Istotny czynnik stanowi w nich również uproszczony proces komunikowania się. Posiadając profil w serwisie społecznościowym, można w szybki sposób przekazać informację dużej grupie odbiorców bądź ją pozyskać. Dodatkowo portale społecznościowe dają szansę odnalezienia dawnych przyjaciół oraz podtrzymywania znajomości, a co za tym idzie - kreowania szerokiej sieci relacji społecznych. 
Ta grupa znanych ludzi, którą posiada użytkownik, często określa jego osobowość. Nieistotne wydają się więzi łączące go z ludźmi, którzy widnieją na jego profilu, ponieważ często to sam kontakt stanowi wartość, którą można się pochwalić [Kapralska 2010, s. 270-271]. Co więcej, w aspekcie użyteczności za ich pośrednictwem internauci zyskują możliwość współpracowania (wymieniania się pomysłami oraz tworzenia innowacyjnych projektów) $\mathrm{z}$ innymi odbiorcami $\mathrm{z}$ całego świata, a tym samym funkcjonowania w międzynarodowych społecznościach [Sokołowski 2008, s. 346].

Serwisy i portale społecznościowe organizujące niemal codzienne życie wydają się zatem sposobem na znalezienie podobnych ludzi w celu stworzenia $\mathrm{z}$ nimi wirtualnej wspólnoty. Warto jednak pamiętać, że w korzystaniu z nich nie istnieją żadne reguły. Wiek, wykształcenie czy inne czynniki nie warunkują ich użytkowania. Zmienne są natomiast cele oraz korzyści, jakie czerpią z nich poszczególne grupy odbiorców.

\section{Facebook jako medium społecznościowe}

Facebook (wcześniej: Thefacebook) [Bio.] jest najpopularniejszym portalem społecznościowym na świecie. W ramach jego struktury użytkownicy tworzą grupy. Dzielą się informacjami, zdjęciami, filmami, a także korzystają z różnych gier i aplikacji. Początkowo miał służyć odnajdywaniu i utrzymywaniu kontaktów z innymi użytkownikami. Dziś stał się gigantem, na którym opierają się pomysły wielu innych serwisów.

4 lutego 2004 roku Mark Zuckerberg wraz z grupą innych studentów Uniwersytetu Harvarda stworzył platformę on-line - serwis społecznościowy łączący ludzi, będący miejscem spotkań psychologii i technologii, który okazał się strzałem w dziesiątkę. Utworzenie kodu źródłowego zajęło im około dwóch tygodni. Początkowo miał być przeznaczony dla licealistów oraz studentów szkół wyższych, którzy dzięki niemu mogli odszukiwać i kontynuować szkolne znajomości [Forbes 2008]. Bardzo szybko jednak zyskał uznanie użytkowników. W pierwszych dwóch tygodniach funkcjonowania na stronie zarejestrowało się ponad dwie trzecie studentów. Wówczas twórcy postanowili rozszerzyć działanie serwisu na inne szkoły. Latem 2004 roku działalnością objęto aż 30 uczelni, a powstające przedsiębiorstwo doczekało się inwestora. Tworząca się firma znalazła pierwszą siedzibę na University Avenue w centrum Palo Alto w Kalifornii. Obecnie mieści się w czterech budynkach w Menlo Park nazywanych przez samego Zuckerberga „kampusem miejskim" [Protalinski 2008].

8 kwietnia 2009 roku Facebook po raz pierwszy przestał przynosić straty, a zaczął pokrywać swoje koszty [tm, AFP 2009]. 18 maja 2012 roku jako firma pojawił się na amerykańskiej giełdzie NASDAQ. Stał się wówczas najwyżej wycenianą w dniu debiutu spółką giełdową w historii [Grynkiewicz 2012]. 
W kilka lat serwis społecznościowy utworzony przez bardzo zdolnego studenta stał się światowym fenomenem kulturowym i socjologicznym [Olszański 2012, s. 98]. Choć od powstania przeszedł wiele modyfikacji, to niezmiennie daje szerokim masom internautów narzędzia, które pozwalają dzielić się informacjami bez udziału mediów. Zamieszczenie wiadomości na facebookowej ścianie wymaga założenia konta. Trwa to około minuty. Grupę odbiorców treści danego użytkownika stanowią jego zaakceptowani i przyjęci znajomi. Każda opublikowana informacja trafia najpierw do tejże grupy. Jej odbiorcy z kolei mogą ją bardzo łatwo udostępnić swoim znajomym za pomocą zaledwie jednego kliknięcia. W ten sposób w kilka sekund dochodzi do efektywnie działającej sieci przekazywania informacji [Olszański 2012, s. 98].

Facebook oferuje też wewnętrzną platformę aplikacji internetowych. Stanowi ona jeden ze sposobów zarobku twórców poprzez oferowanie zawartości premium, którą zazwyczaj są dodatkowe przedmioty w grach bądź wirtualne pieniądze. Platforma stwarza możliwość łączenia się Facebooka z innymi programami zewnętrznymi czy serwisami internetowymi; umożliwia podpinanie konta. Logując się do innego serwisu, wykorzystuje się dane logowania z Facebooka [Yadav 2006]. Przykładem takiego portalu jest filmweb.pl.

Serwis, poza publikowaniem własnych wiadomości w formie postów na ścianie, udostępnia wewnętrzny komunikator, pozwalający porozumiewać się z innymi użytkownikami na zasadzie czatu. Oprócz tego posiada standardowe funkcje obecne w każdym portalu społecznościowym - albumy ze zdjęciami, blog, książkę adresową, notes, grupy zamknięte oraz listę znajomych.

Dziś trudno jednak oprzeć się wrażeniu, że cel i przeznaczenie Facebooka wymknęło się spod kontroli. Portal już od dawna nie służy prowadzeniu komunikacji między znajomymi. Stał się maszyną do kreowania wizerunku. Zdaniem Wiesława Godzica: „Myśląc o Facebooku i celebrytach, nie trzeba się ekscytować: oto gwiazdy i gwiazdeczki otrzymały tanie i skuteczne narzędzie do promocji. Mogą sprawnie zarządzać fanpage’ami dzięki temu, że widzą nawet drobne wahnięcia liczby fanów" [Kiedrzyńska-Tui 2014].

\section{Kampanie społeczne a social media. Kampanie na Facebooku}

To podobieństwo internetowej rzeczywistości do świata realnego sprawiło, że ludzie czują naturalną potrzebę przedstawienia własnej osoby. Kreowanie pozytywnego wizerunku stanowi czynność występującą u każdego człowieka. Rozciąga się w czasie od zarania życia do późnej starości [Kiszkiel 2013, s. 179]. Podświadomość podpowiada, że od właściwej autokreacji zależy zarówno podziw, jak i autorytet jednostki w społeczeństwie. Dlatego człowiek instynktownie stara się sprawić wrażenie osoby błyskotliwej, kreatywnej, inteligentnej, energicznej, zabawnej oraz atrakcyjnej fizycznie na jak największej liczbie osób [Kiszkiel 2013, s. 179]. 
Najważniejsze okazuje się jednak wywarcie takiego wrażenia, które będzie opłacalne. Owa opłacalność wynika niestety z ilości. Do uzyskania zadowalającego rezultatu służy Internet, który umożliwia nie tylko eksperymentowanie $\mathrm{z}$ tożsamością, ale przede wszystkim robienie tego na szeroką skalę.

Choć - jak pisał Tomasz Goban-Klas - ze względu na swój zasięg Internet „(...) stanowi idealne miejsce dla rozlicznych działań szkodliwych, a jednocześnie trudnych do identyfikacji, lokalizacji i eliminacji" [Goban-Klas 2005, s. 228], to jednak także dobre miejsce dla społecznej edukacji. Dlatego media społecznościowe stały się doskonałym narzędziem uzupełniającym i wspomagającym działania marketingowe. Zainteresowanie się nimi przez marketing społeczny, a dokładniej kampanie społeczne spowodował wspomniany czynnik ilościowy odbiorców, czyli szybki i globalny przepływ ważnych społecznie informacji, ale również konieczność doganiania lub prześcigania konkurencji tak w zakresie zasięgu, skuteczności, jak i pomysłowości dotarcia. W powszechnym, choć niestety błędnym odbiorze kampanie społeczne kojarzone są zwykle z czynnościami i akcjami charytatywnymi. Nie powinny, ponieważ działania takie mogą stanowić wyłącznie dodatek do nich.

Dlatego też nadawcy kampanii społecznych, mając na celu zmianę zarówno zachowań czy opinii w konkretnej kwestii, jak i postaw wobec danego problemu poprzez promowanie określonych wartości, zachęcanie do zachowań pożądanych lub zniechęcanie do zachowań negatywnych, wydają się przekonani, że dzięki ich działaniom za pomocą właśnie tego narzędzia społeczne życie staje się bardziej świadome, spójne, kulturalne, bezpieczne, życzliwe, oparte na zaufaniu i szacunku. Co ciekawe, skuteczna zmiana postawy stanowi wynik całkowitego zinternalizowania propagowanych przez kampanię społeczną wartości [Lusińska 2015; Kalinowska-Żeleźnik, Lusińska 2012].

Najczęściej spotykane w sieci kampanie dotyczą problemów ruchu drogowego, promocji zdrowia oraz równouprawnienia. Określane są jako skuteczne, ale niepozbawione wad. Propagowane przez nie treści giną wśród wielu innych udostępnianych przez użytkowników. Problem może wynikać ze zbyt małych budżetów na promocję kampanii społecznych, przez co nie mają one szans wybicia się ponad komunikaty dużych marek o wysokim budżecie i szerokim zasięgu. Jednak w aspekcie pozytywnym social media znacznie częściej pozwalają na dotarcie do odbiorców sprofilowanych. Dają wówczas możliwość tworzenia wysoce ukierunkowanych kampanii kierowanych do wąskich grup zainteresowań.

W kontekście kampanii społecznych dało się też wreszcie zauważyć wykorzystywanie potencjału takich serwisów jak Facebook, choć liczne instytucje non profit zawsze miały problem $\mathrm{z}$ promocją ważnych społecznie komunikatów $\mathrm{w}$ tradycyjnych mediach. Musiały liczyć na ich łaskę, aby te zechciały wyemitować czy opublikować darmowy przekaz. Wraz z nadejściem Facebooka sporo się w tej kwestii zmieniło. Budżet kampanijny przestał być tak istotny jak kiedyś. Zaczął liczyć się pomysł. 
Media tradycyjne, żądne newsów i nowych tematów, obserwujące z zazdrością setki tysięcy niesklasyfikowanych użytkowników - aktywnych liderów w swoich środowiskach [Łukasik 2010], którzy szybko udostępniali i komentowali wytypowaną treść, „lajkując”, „hejtując”, „szerując” wśród swoich znajomych w miejscu zamieszkania czy pracy, stale poszerzając zasięg materiału, docierającego do coraz większej liczby potencjalnych odbiorców, zaczęły także interesować się najczęściej kontrowersyjnymi w swej formie kampaniami społecznymi zainicjowanymi na Facebooku. Dzięki temu popularyzowane wartości docierały do szerszej publiczności, przyczyniając się do osiągnięcia ostatecznego celu.

Prowadzenie kampanii społecznych na Facebooku stwarza duże możliwości. Facebook, jako narzędzie oferujące internautom niespotykane dotąd na innych portalach społecznościowych możliwości promocji, takie jak na przykład fanpagee (czyli strony będące połączeniem zwykłych stron internetowych, forów dyskusyjnych i blogów, skupiające swoich fanów, a dokładniej profile osób, które interesują się aktywnie stroną, dające także możliwość komunikowania się tychże - komentowania wpisów oraz codziennego aktualizowania zawartości strony), pozwala za ich pomocą promować różne przedsięwzięcia. Standardem stało się więc zamieszczanie na takiej stronie bez ograniczeń czasowych zdjęć czy spotów reklamowych, na przykład z poparciem znanych osób, licznych raportów i analiz przedstawiających w sposób naukowy dany problem [Eukasik 2010].

I choć facebookowe kampanie z niezwykłą delikatnością, wyczuciem i intuicją społeczną starają się mocno przemawiać do emocji, angażując bezpośrednio swoich użytkowników - małe, socjometryczne gwiazdy, poprzez posiłkowanie się ich aktywnościami w Internecie, które, co ciekawe, zostają dogłębnie prześwietlone i zinwigilowane przez wyspecjalizowane komórki za ich dobrowolną zgodą, to ich skuteczność nie zawsze jest tożsama z prognozowaną. Problem tkwi w tym, że z powodu nadmiernej ilości danych i bezwysiłkowego, wręcz mechanicznego ich przesyłu (poprzez „lubienie” różnych treści) użytkownicy Facebooka, choć reklamy społecznej ani zachęty do odwiedzenia profilu kampanii na Facebooku nie traktują jako spamu i pieczołowicie propagują cele kampanii, to jej samej nie zapamiętują. Niestety, zgodnie ze słowami Winstona Churchilla, że wszystko, co przedstawia wartość, wymaga wysiłku, współcześnie nadużywane słowo „lubię” straciło pierwotną moc, zaangażowanie i przełożenie na rzeczywistość.

Jak widać, prowadzenie kampanii społecznych na Facebooku do łatwych nie należy, ponieważ w ostatnim czasie stał się on narzędziem głównie rozrywkowym. Poruszanie więc $\mathrm{w}$ takim otoczeniu tematów trudnych i poważnych stanowi nie lada wyzwanie. 


\subsection{Kampanie społeczne na i o Facebooku}

„Nie masz Facebooka? Nie istniejesz” - twierdzą współcześni młodzi przedstawiciele generacji X, Y i Z, dryfujący na szybkich łączach ponad granicami zglobalizowanego świata. W nim kreują swój wizerunek - zawodowy, prywatny, intymny. Wyznawana przez nich idea zakłada, że im więcej masz znajomych na tym portalu, tym lepiej. Dla nich życie bez Internetu i mediów społecznościowych nie tylko byłoby trudniejsze, ale z pewnością nie miałoby sensu. Jednak Facebook to nie życie, o czym nietrudno się przekonać, zwłaszcza że świat poinformowała już o tym kampania Polskiego Czerwonego Krzyża (PCK) pt. „Życie to nie Facebook”.

Facebook w ujęciu PCK stanowi miejsce obalania reżimu, w którym wszystkich informuje się niemal o wszystkim - pasjach, przemyśleniach, a nawet urlopie. $\mathrm{Na}$ nim widnieją najlepsze zdjęcia jego użytkowników i te, o których woleliby oni zapomnieć. Przyjmując obcego do grona znajomych na Facebooku, zapraszają go oni do swojego intymnego świata. Polski Czerwony Krzyż postanowił więc ostrzec owych internautów, że podobna nieostrożność w realu może mieć fatalne skutki, i na listopad 2010 roku zaplanował kampanię edukacyjną, której realizację powierzył agencji Saatchi \& Saatchi Poland [Saatchi \& Saatchi Digital 2012].

Na jej potrzeby na Facebooku stworzony został specjalny, fikcyjny profil bardzo atrakcyjnej dziewczyny - Ali Skoczewskiej, nieświadomej zakażenia wirusem HIV, zapraszającej za pomocą narzędzia friend request do grona znajomych losowo wybranych użytkowników serwisu. Już w kilka chwil od rozpoczęcia akcji ponad tysiąc osób przyjęło do znajomych absolutnie obcą osobę, widząc jedynie jej zdjęcie. Tymczasem na profilu dziewczyny czekał na nich tylko jeden post - film [PCK 2011b] z udziałem Ali, pokazujący prostotę i szybkość nawiązywania często powierzchownych, niepewnych znajomości, które wymusiła na odbiorcach era portali społecznościowych, a także jak ich pochopna decyzja sprzed chwili wyglądałaby w świecie rzeczywistym. Bo zauroczenie ładną buzią i przyjęcie zaproszenia do podzielenia się swoją intymnością w realu grozi konsekwencjami, z których nie da się wylogować. Może prowadzić do zakażenia się wirusem HIV, co też ukazuje finałowa scena filmu, której hasło brzmi: „Ala ma HIV. Teraz masz i ty. Życie to nie Facebook. Nie przyjmuj zaproszenia od nieznajomych" [PCK 2011a].

Co roku na świecie umierają dwa miliony ludzi, a z wirusem HIV żyje około 33 milionów. Z danych Krajowego Centrum do spraw AIDS oraz PCK wynika, że w Polsce rocznie dochodzi do ponad 800 zakażeń wirusem HIV (zarażają się nim średnio trzy osoby dziennie). Między 1985 a 2011 rokiem wykryto ponad 15 tysięcy przypadków zarażenia, ale specjaliści oceniają, że zakażonych Polaków może być nawet 35 tysięcy, z czego nawet 70\% nie wie o swojej chorobie. Najliczniejszą grupę, bo aż $84 \%$ wśród żyjących z HIV/AIDS, stanowią niestety głównie ludzie młodzi w wieku produkcyjnym, mający 20-49 lat (46\% zakażonych nie ukończyło 29. roku życia, w tym 7\% w momencie zakażenia nie miało 20 lat). Co ciekawe, mimo wielu kampanii na temat profilaktyki świadomość dotycząca łatwości, z jaką można 
stać się nosicielami HIV, w Polsce wciąż jest niewielka. Badania zrealizowane przez TNS OBOP pokazują, że to właśnie kontakty seksualne (niemal 80\% przypadków) są głównym źródłem zarażenia. Jednak tylko co piąty Polak pyta swojego partnera o zagrożenie AIDS i testy w kierunku HIV [PCK 2011a].

Jako że edukację oraz wypracowywanie odpowiednich wzorców zachowań ograniczających ryzyko zakażenia uznaje się za efektywną metodę, informacje o akcji szybko trafiły na główne strony najważniejszych portali. Największe stacje telewizyjne wtórowały nadawcy w apelu o ostrożność i badanie krwi. Co ciekawe, po zaledwie dwóch dniach kampanię komentowały także amerykańskie media. Film o akcji już po dwóch tygodniach miał ponad dwa miliony odsłon, wywołując dyskusje o profilaktyce HIV aż w 150 krajach. Najważniejsze jednak, że w pierwszym miesiącu jej trwania (listopad 2010) liczba testów na obecność wirusa wzrosła aż o 43\% w porównaniu z poprzednim rokiem [Saatchi \& Saatchi Digital 2012].

Zatem cel kampanijnych działań, którym uczyniono poszerzenie świadomości na temat potencjalnych zagrożeń HIV oraz negatywnych konsekwencji otwartości i bezpośredniości, której uczą serwisy społecznościowe na czele z Facebookiem [km 2011; Kamińska 2012], a także przenoszenia mechanizmów szybkiej i płytkiej komunikacji internetowej do codziennego życia, zwłaszcza w sferę kontaktów seksualnych, został osiągnięty. Kampania wpisała się w Światowy Dzień AIDS przypadający 1 grudnia. Zarówno ją, jak i agencję Saatchi \& Saatchi Poland wielokrotnie nagradzano [PCK 2012].

\section{Zakończenie}

Choć Facebook nie służy podtrzymywaniu relacji z ludźmi, lecz tworzeniu doświadczeń społecznych, to okazuje się, że pewnych znajomych lepiej byłoby nie mieć. Dlaczego więc użytkownik oddaje swój los wirtualnym sieciom? Ponieważ wykonując pracę, może otworzyć dodatkowe okno w przeglądarce i porozmawiać ze znajomymi czy poznać nowych, by po wielu godzinach w niej spędzonych, zamiast pójść na imprezę, wrócić do domu i ponownie włączyć komputer. Wydaje się to szybszym i mniej kompromitującym sposobem niż zaczepianie obcych kobiet czy mężczyzn w barze. Do tego nieraz wirtualne randki kończą się spotkaniem w realu. Ma ów użytkownik zatem najzwyczajniej tendencję do bagatelizowania niebezpieczeństw, bo kiedy dochodzi do spotkania, odsuwa od siebie zagrożenia, nie myśląc o konsekwencjach.

Kontakty przez Internet, a zwłaszcza poprzez media społecznościowe, z których korzysta bardzo wiele osób, to już nie wstyd, ale - wydawać by się mogło - najlepsze wyjście z sytuacji osamotnienia. Tym bardziej, że tylko tu występuje poczucie, iż w każdej chwili można wycofać się ze znajomości. Przypuszczenia te potwierdzają badania. Prawie 25\% dorosłych internautów poznaje kogoś w sieci (Kamińska 2012). Jednak prawdziwym, niezwykle poważnym problemem nie jest 
poszukiwanie internetowych znajomości, lecz nieodpowiedzialność podczas spotkań w rzeczywistości. Niektórzy uważają więc - a ludzi tych zaczyna przybywać (i to nie ze względu na modę) - że dziś dobrze jest po prostu nie mieć Facebooka.

\section{Bibliografia}

Barefoot D. (2011), Znajomi na wage złota: podstawy marketingu w mediach społecznościowych, Wolters Kluwer Polska, Warszawa.

Bendyk E. (2009), Większa połowa, „Polityka”, 12.10.2009, http://www.polityka.pl/rynek/ gospodarka/285853,1,raport-internet-w-polsce-ad-2009.read\#ixzz1yi6GYUQO (dostęp: 18.08.2015).

Bio., Mark Zuckerberg Biography, http://www.biography.com/people/mark-zuckerberg-507402\#the-rise-of-facebook\&awesm= oGJiKCTq4SFWea (dostęp: 18.08.2015).

Brigs A., Burke P. (2010), Społeczna historia mediów: od Gutenberga do Internetu, tłum. J. Jedliński, Wydawnictwo Naukowe PWN, Warszawa.

Forbes (2008), \#785 Mark Zuckerberg, „Forbes”, 3.05.2008, http://www.forbes.com/ lists/2008/10/billionaires08_Mark-Zuckerberg_I9UB.html (dostęp: 18.08.2015).

Goban-Klas T. (2005), Cywilizacja medialna, WSiP, Warszawa.

Gogołek W. (2010), Komunikacja sieciowa. Uwarunkowania, kategorie i paradoksy, Oficyna Wydawnicza ASPRA-JR, Warszawa.

Grynkiewicz T. (2012), Facebook na giełdzie. Debiut, jakiego internet nie widział, Wyborcza.pl, 18.05.2012, http://wyborcza.biz/biznes/1,101562,11752978,Facebook_na_gieldzie_Debiut_jakiego_internet_nie.html (dostęp: 18.08.2015).

Kalinowska-Żeleźnik A., Lusińska A. (2012), Współpraca instytucji publicznych i mediów masowych $w$ zakresie przeciwdziałania problemom społecznym na przykładzie kampanii pt.: Nie krzywdź, a nie będziesz krzywdzony, [w:] A. Kalinowska-Żeleźnik, A. Lusińska, J. Maćkiewicz (red.), Maski dziennikarstwa. Księga poświęcona prof. dr. hab. Wiktorowi Peplińskiemu, Wydawnictwo Bernardinum, Pelplin.

Kamińska K. (2012), Życie to nie Facebook - dlaczego oddajemy los w ręce internetu?, na:Temat, http://natemat.pl/2749,zycie-to-nie-facebook-dlaczego-oddajemy-los-w-rece-internetu (dostęp: 25.08.2015).

Kaplan A.M., Haenlein M. (2010), Users of the World, Unite! The Challenges and Opportunities of Social Media, „Business Horizons”, nr 53(1), http://michaelhaenlein.com/Publications/ Kaplan,\%20Andreas\%20-\%20Users\%20of\%20the\%20world,\%20unite.pdf, s. 61 (dostęp: 17.08.2015).

Kapralska Ł. (2010), O komunikacyjnych i integracyjnych funkcjach serwisów społecznościowych, [w:] M. Niezgoda, M. Świątkiewicz-Mośny, A. Wagner, Com.unikowanie w zmieniającym się społeczeństwie, Zakład Wydawniczy Nomos, Kraków.

Kaznowski D. (2008), Nowy marketing, VFP Communications, Warszawa.

Kiedrzyńska-Tui A. (2014), 10 lat Facebooka, http://www.swps.pl/strefa-psyche/blog-strefy-psyche/11857-10-lat-facebooka (dostęp: 20.08.2015).

Kiszkiel Ł. (2013), Wirtualne tożsamości. Portale społecznościowe jako formy autokreacji, [w:] M. Sokołowski (red.), Nowe media $i$ wyzwania współczesności, Wydawnictwo Adam Marszałek, Toruń.

km (2011), „Życie to nie Facebook” - PCK ostrzega przed HIV (wideo), WirtualneMedia.pl, 21.11.2011, http://www.wirtualnemedia.pl/artykul/zycie-to-nie-facebook-pck-ostrzega-przed-hiv-wideo (dostęp: 25.08.2015). 
Konkurs. Kampania Społeczna Roku 2011, http://konkurs.kampaniespoleczne.pl/Raport_z_ konkursu_2011.pdf (dostęp: 25.08.2015).

Levinson J.C., Gibson S. (2011), Marketing partyzancki w mediach społecznościowych. 126 narzędzi w walce o pozycje w Internecie, tłum. M. Grala-Kowalska, Wolters Kluwer Polska, Warszawa.

Lusińska A. (2015), Ważność mediacji w sporze propagowana w mediach masowych na przykładzie rzadowej kampanii społecznej pt.: „Masz prawo do mediacji”, „Zeszyty Prasoznawcze. Mediatyzacja życia - zjawisko i konteksty", nr 1.

Łukasik M. (2010), Czy jest sens prowadzenia kampanii społecznych na Facebooku?, http://www. biznes-firma.pl/czy-jest-sens-prowadzenia-kampanii-spolecznych-na-facebooku/16476 (dostęp: 22.08.2015).

Olszański L. (2012), Media i dziennikarstwo internetowe, Wydawnictwo Poltext, Warszawa.

PCK (2011a), Uważaj na HIV. Życie to nie Facebook!, http://www.pck.pl/news,981.html (dostęp: 25.08.2015).

PCK (2011b), „Życie to nie Facebook”, www.youtube.com/watch?v=LgBHZTR3iCw (dostęp: 25.08.2015).

PCK (2012), Życie to nie Facebook Kampaniq Społeczna Roku 2011, http://www.pck.pl/ news, 1098.html (dostęp: 25.08.2015).

Protalinski E. (2008), Facebook Completes Move from Palo Alto to Menlo Park, ZDNet, 19.12.2011, http://www.zdnet.com/blog/facebook/facebook-completes-move-from-palo-alto-to-menlo-park/6489 (dostęp: 18.08.2015).

Saatchi \& Saatchi Digital (2012), Podsumowanie naszej akcji „Życie to nie facebook”. Dziękujemy Saatchi!, https://pl-pl.facebook.com/PolskiCzerwonyKrzyz/posts/237188316380552 (dostęp: 25.08.2015.

Sadowski M. (2013), Rewolucja social media, Wydawnictwo Helion, Gliwice.

Sokołowski M. (2008), Nowe strategie komunikacyjne, Wydawnictwo Adam Marszałek, Toruń.

Śliwińska K. (2011), Narzędzia i techniki komunikacji marketingowej XXI wieku, Oficyna Wolters Kluwer Business, Warszawa.

tm, AFP (2009), Serwis Facebook ma 200 milionów użytkowników, Gazeta.pl, 8.04.2009, http:// wiadomosci.gazeta.pl/wiadomosci/1,114873,6481732,Serwis_Facebook_ma_200_milionow_uzytkownikow.html (dostęp: 18.08.2015).

tomek (2013), Social Media - Czym sa media społecznościowe, http://www.marketinginternetowy.pl/social-media-czym-sa-media-spolecznosciowe/ (dostęp: 17.08.2015).

Tur H. (2015), Liczba użytkowników Facebooka rośnie i rośnie..., PCWorld, 30.01.2015, http:// www.pcworld.pl/news/400763/Liczba.uzytkownikow.Facebooka.rosnie.i.rosnie.html (dostęp: 17.08.2015).

Yadav S. (2006), Facebook - The Complete Biography, Mashable, 25.08.2006, http://mashable. com/2006/08/25/facebook-profile/ (dostęp: 19.08.2015). 